\title{
Advanced exergetic analysis of a heat pump providing space heating in built environment
}

\author{
Volodymyr A. Voloshchuk \\ National Technical University of Ukraine \\ "Igor Sikorsky Kyiv Polytechnic Institute", \\ Politehnichna St. 56, \\ 03056 Kyiv, Ukraine \\ E-mail Vl.Volodya@gmail.com
}

In addition to conventional exergy-based methods, advanced exergetic analyses consider the interactions among components of the energy-conversion system and the real potential for improving each system component.

The paper demonstrates the results of application of a detailed advanced exergetic analysis to a wastewater source heat pump providing space heating in the built environment. In order to determine thermodynamic parameters of the refrigeration vapour compression cycle in different operating modes, the simulation model has been used. The analysis includes splitting the exergy destruction within each component of a heat pump into unavoidable, avoidable, endogenous and exogenous parts as well as detailed splitting of the avoidable exogenous exergy destruction. Besides, variabilities of heating demands of a building within both the chosen heating season and also from year to year are taken into account. Distribution of the split exergy destructions during different periods of time is also presented for the analysed cases of the heat pump and built environment. It is shown that in the investigated system only about $50 \%$ of the total annual destruction in components of the heat pump can be avoided. About $30 \ldots 40 \%$ of this avoidable thermodynamic inefficiency is caused by interactions among components. Based on the applied advanced exergetic analysis it is possible to receive more precise and useful information for better understanding and improving the design and operation of the analysed energy-conversion system.

Keywords: advanced exergetic analysis, heat pump, space heating, variability

\section{INTRODUCTION}

The exergy-based methods provide information concerning location, magnitude and causes of thermodynamic inefficiencies in an energy-conversion system [1-6].
In addition to conventional exergetic evaluation, the so-called advanced exergetic analysis and its methodologies have been developed at the Institute for Energy Engineering of Technische Universität (TU) Berlin in the past twenty years [1-4]. 
Advanced exergetic analysis can significantly reduce the most important limitations of a conventional analysis by evaluating the detailed interactions among components of the overall system and the real potential for improving a system component. The main objective of advanced exergy-based analyses is to provide engineers with additional useful information for a better understanding and improving the design and operation of energy-conversion systems. This information cannot be supplied by any other approach.

According to the current knowledge of the author, advanced exergy analyses have been applied mostly to refrigeration machines and industrial heat pump systems where only single modes (design or nominal ones) were investigated [2-6]. A distinguished feature of the heat pump systems providing thermal comfort in buildings is the variation of operational regimes. This is caused mainly by climate and weather conditions (temperatures, solar radiation, wind velocity, pressure, humidity, etc.). All those factors change randomly and the tempo is different over different time periods under consideration. This feature should be taken into account when applying exergy-based methods to heat pump systems providing space heating.

So, the scope of the paper is to demonstrate the application of advanced exergetic analysis to a heat pump providing space heating in varying operational modes, which is typical of the built environment and caused by fluctuating outdoor conditions.

\section{METHODOLOGY}

The analysis is performed for a typical Ukrainian house. The dwelling has two floors with a gross floor area of $170 \mathrm{~m}^{2}$ and a volume of $470 \mathrm{~m}^{3}$. The weighted average insulation value of non-glazed external surfaces is $0.5 \mathrm{~W} /\left(\mathrm{m}^{2} \cdot \mathrm{K}\right)$. The $\mathrm{U}$-value of windows including frames is $1.6 \mathrm{~W} /\left(\mathrm{m}^{2} \cdot \mathrm{K}\right)$. Internal heat gains are defined with a constant value of $5 \mathrm{~W} / \mathrm{m}^{2}$. Setpoint for the indoor temperature is $18^{\circ} \mathrm{C}$. The fraction of east and west oriented glazing is $30 \%$, of the south one $-50 \%$, of the north one $-20 \%$. Natural ventilation is used in the dwelling. the design heating capacity of the house is $25 \mathrm{~kW}$. Hydronic system is used for space heating. The heat pump is a ba- sic heater covering $12 \mathrm{~kW}$ of heating demand in the design mode and uses sewage water as a low temperature heat source. R134A is chosen as a working fluid in the heat pump.

The quality of the conclusions obtained from a conventional exergetic evaluation can be improved, when the exergy destruction in each system component is split into endogenous/exogenous parts $\left(\dot{E}_{D, k}=\dot{E}_{D, k}^{E N}+\dot{E}_{D, k}^{E X}\right)$, unavoidable/ avoidable parts $\left(\dot{E}_{D, k}=\dot{E}_{D, k}^{A V}+\dot{E}_{D, k}^{U N}\right)$, and combined according to the two approaches of splitting $\left(\dot{E}_{D, k}=\dot{E}_{D, k}^{E N, U N}+\dot{E}_{D, k}^{E X, U N}+\dot{E}_{D, k}^{E N, A V}+\dot{E}_{D, k}^{E X, A V}\right)$. The analysis based on these procedures is called advanced exergetic analysis and proposed in [1-4].

The endogenous part of exergy destruction $\left(\dot{E}_{D, k}^{E N}\right)$ is associated only with the irreversibilities occurring in the kth component when all other components operate in an ideal way and the component being considered operates with its current efficiency.

The exogenous part of exergy destruction $\left(\dot{E}_{D, k}^{E X}\right)$ is caused within the kth component by the irreversibilities that occur in the remaining components.

The unavoidable exergy destruction $\left(\dot{E}_{D, k}^{U N}\right)$ cannot be further reduced due to technological limitations, such as availability and cost of materials and manufacturing methods.

The difference between total and unavoidable exergy destruction for a component is the avoidable exergy destruction $\left(\dot{E}_{D, k}^{A V}\right)$ that should be considered during the improvement procedure.

To better understand the interactions among components, the exogenous exergy destruction within the kth component should also be split.

For obtaining a deeper understanding of the interactions among components, the exogenous exergy destruction (as well as the exogenous unavoidable and the exogenous avoidable exergy destructions) within the kth component are split:

$$
\dot{E}_{D, k}^{E X}=\sum_{\substack{r=1 \\ r \neq k}}^{n-1} \dot{E}_{D, k}^{E X, r}+\dot{E}_{D, k}^{\text {mexo }},
$$

where $\dot{E}_{D, k}^{E X, r}$ represents part of the exogenous exergy destruction within the kth component that is caused by the irreversibilities occurring within the rth component;

$\dot{E}_{D, k}^{\text {mexo }}$ - the remaining part is called mexogenous exergy destruction (from mixed exogenous 
exergy destruction) within the kth component and is caused by the combined interactions of three or more components.

To identify the importance of the components from the thermodynamic viewpoint and priorities for improving the components, the investigator should use the sum of the avoidable endogenous exergy destruction within the kth component $\dot{E}_{D, k}^{A V E N}$ and of the avoidable exogenous exergy destructions within the remaining components caused by the kth component $\sum_{\substack{r=1 \\ r \neq k}}^{n-1} \dot{E}_{D, r}^{A V, E X, k}$

$$
\dot{E}_{D, k}^{A V, \Sigma}=\dot{E}_{D, k}^{A V, E N}+\sum_{\substack{i=1 \\ i \neq k}}^{n-1} \dot{E}_{D, r}^{A V, E X, k}
$$

To split exergy destructions into the abovementioned parts, the thermodynamic-cyclebased approach was used [2-4]. The product of the heat pump in all analysed cycles remains unchanged.

In the design operating conditions (nominal mode) the following parameter values are set: the low temperature heat source medium is cooled in the evaporator from $12^{\circ} \mathrm{C}$ to $9^{\circ} \mathrm{C}$; the minimal temperature differences in the evaporator $\delta T_{E V}^{\min }$ and the condenser $\delta T_{C D}^{\min }$ are equal to $5 \mathrm{~K}$. The calculated value of the real isentropic efficiency of the compressor in the nominal mode is equal to $88 \%$. For evaluating unavoidable exergy destructions in nominal mode the following parameter values are assumed: the unavoidable temperature differences in the evaporator and the condenser are equal to $1 \mathrm{~K}$ and the unavoidable compressor efficiency is equal to $96 \%$. For creating the theoretical cycle of the heat pump the following assumptions are used: the minimal temperature differences in the evaporator and the condenser are equal to $0 \mathrm{~K}$; the efficiency of the working fluid compression is equal to $100 \%$; the throttling process is replaced by an ideal expansion process [2].

In order to determine thermodynamic parameters of the refrigeration vapour compression cycle in different operating modes (off-design modes) during a heating season, which is typical of such kind of heat pumps, the simulation model has been used. The model is based on quasi-steady state approach [7]. A set of nonlinear equations, involving heat, mass balances, heat transfer and equations for calculation of ther- modynamic properties of working fluids, were utilized. The equations, solved simultaneously with a gradient numerical method, have been established to describe the behaviour of each component and of the system as a whole. During simulation the temperature of heat source in off-design modes varied in the range from $12^{\circ} \mathrm{C}$ to $22^{\circ} \mathrm{C}$.

Daily weather data within a heating season for the city of Rivne located in the western part of Ukraine were used for the analyses. So, 24-hour time step $\tau_{k}$ was assumed for quasi-steady state modelling. The variation of mean daily outdoor temperature was within the range of $-16^{\circ} \mathrm{C}$ and $10^{\circ} \mathrm{C}$. The total value of heating degree days was $3500^{\circ} \mathrm{C} \cdot$ day.

\section{RESULTS AND DISCUSSIONS}

The distribution of the daily total exergy destruction $\dot{E}_{D, k}$ (without splitting) and the sum of avoidable endogenous and avoidable exogenous exergy destruction $\dot{E}_{D, k}^{A V \Sigma}$ (see formula (2)) in the components of the investigated heat pump over a year is shown in Fig. 1. The shares of these parts of exergy destructions as a function of daily heat production in the heat pump are presented in Fig. 2.

Figure 3 illustrates values of different parts (total, avoidable, avoidable endogenous and avoidable exogenous) of annual exergy destructions in the components of the investigated heat pump.

The values of endogenous/exogenous avoidable parts of seasonal (annual) exergy destruction in the compressor, condenser, throttling valve and evaporator of the investigated heat pump are introduced in Fig. 4.

The avoidable parts of seasonal exergy destructions $\dot{E}_{D, k}^{A V \text { year }}$ in the components of the investigated heat pump for warm, middle and cold years are shown in Fig. 5.

Results in Figs. 1, 2, 3 and 4 represent the same heating season corresponding to the middle year (see Fig. 5).

As it is shown in Fig. 1, the absolute values of daily exergy destruction in the components of the investigated heat pump vary within a heating season. Moreover, the shares of these values for the compressor, condenser, throttling valve and evaporator are different in every time-step of the heating season. 


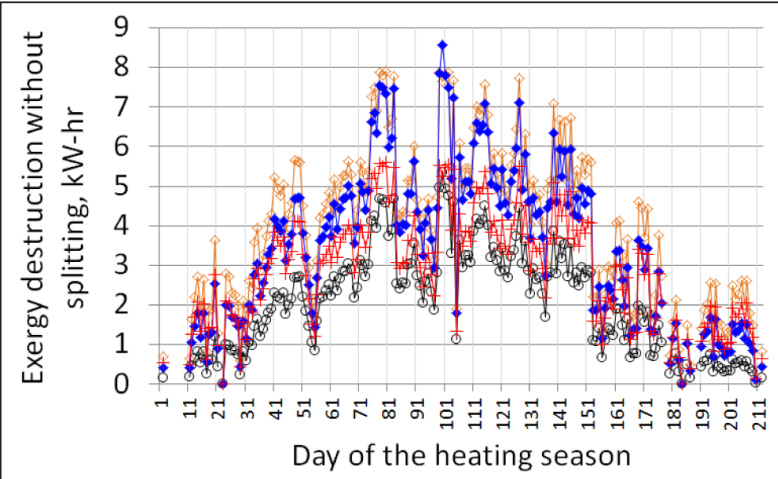

a)

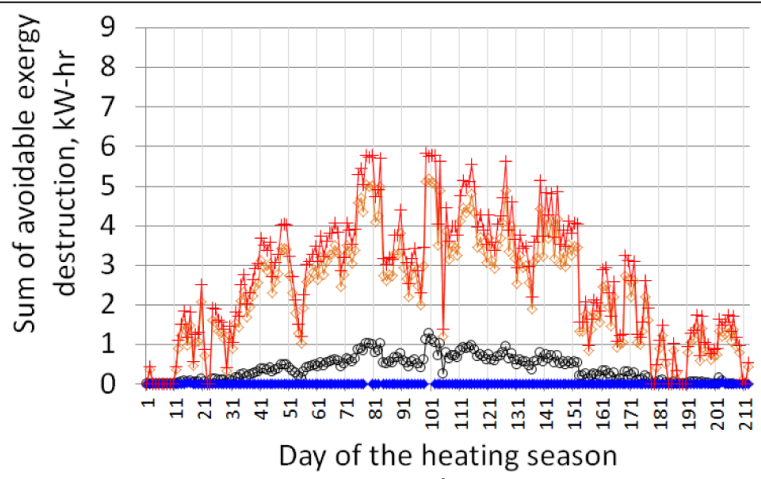

b)

$\bullet$ Compressor $\bullet$ Condenser $\rightarrow$ Throttling valve + Evaporator

Fig. 1. Distribution of daily exergy destruction in the components of the investigated heat pump over a year: a) exergy destruction without splitting $\dot{E}_{D, k^{\prime}} ;$ b) the sum of avoidable endogenous and avoidable exogenous exergy destruction $\dot{E}_{D, k}^{A v, \Sigma}$

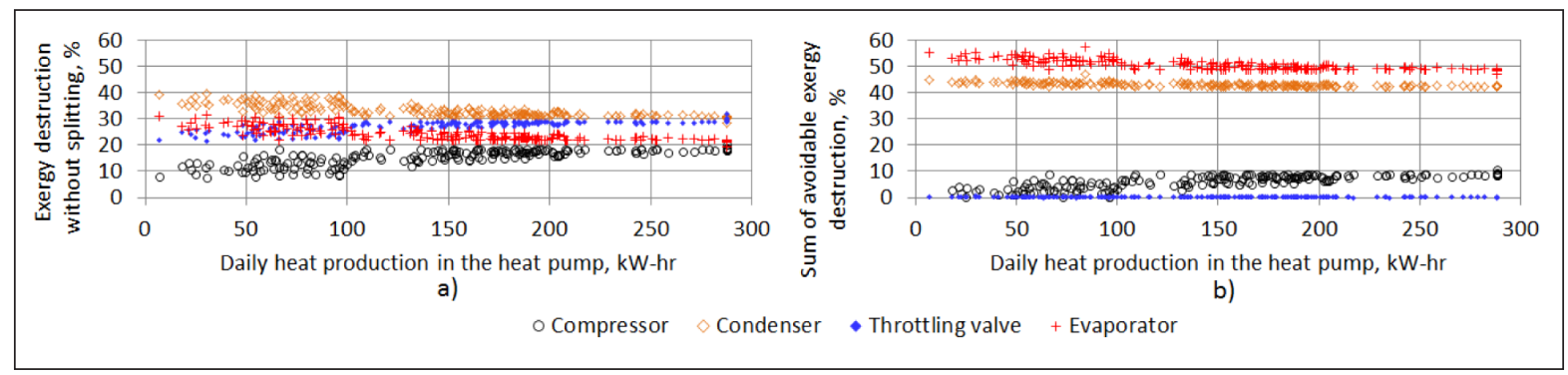

Fig. 2. Shares of daily exergy destruction in the components of the investigated heat pump for different daily heat production in the heat pump: a) exergy destruction without splitting $\dot{E}_{D, k} ;$ b) the sum of avoidable endogenous and avoidable exogenous exergy destruction $\dot{E}_{D, k}^{A v, \Sigma}$

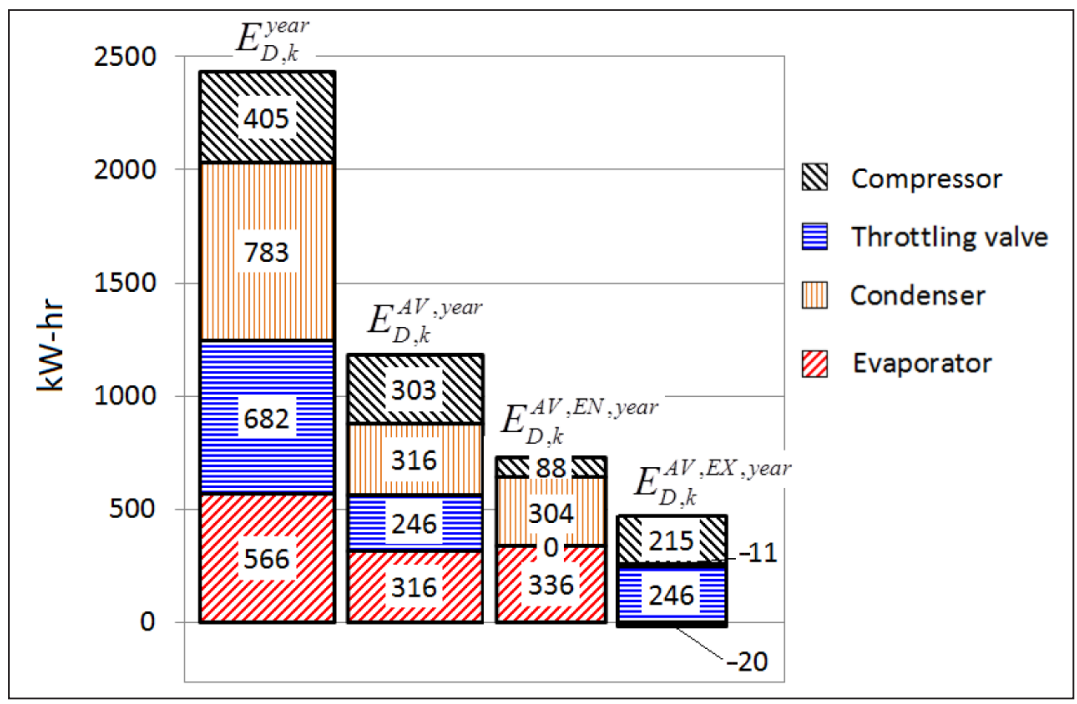

Fig. 3. Values of seasonal exergy destructions in the components of the investigated heat pump

It can be observed from Fig. 2 that the shares of the chosen parts of exergy destruction (without splitting $\dot{E}_{D, k}$ and the sum of avoidable endogenous and avoidable exogenous $\left.\dot{E}_{D, k}^{A V \Sigma}\right)$ depend on daily heat production in the heat pump. For example, within the heating period there are cases where the ratio of the exergy destruction without splitting in the compressor and 


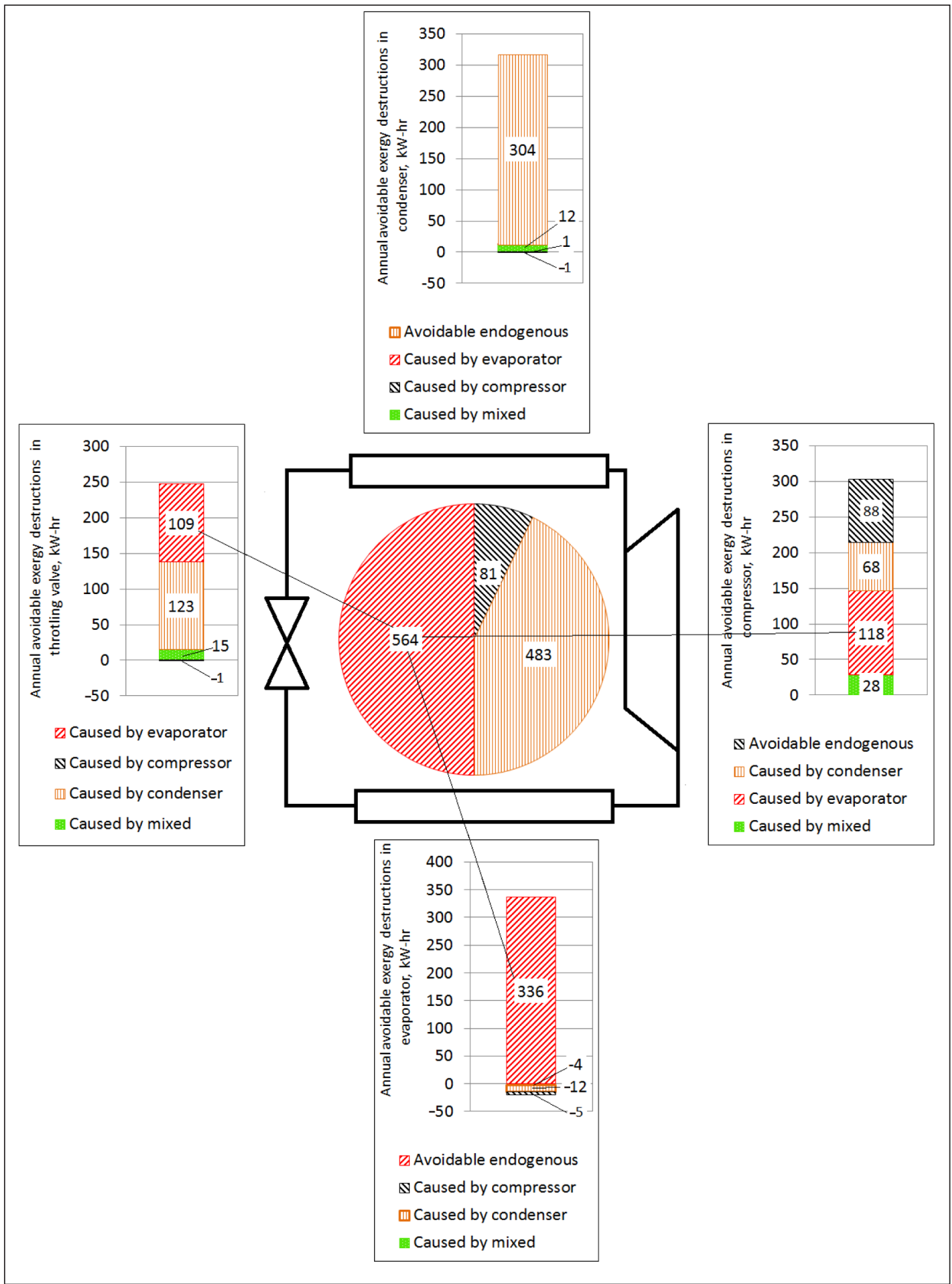

Fig. 4. Values of endogenous/exogenous avoidable parts of seasonal exergy destructions $E_{D, k}^{A V, \Sigma, y e a r}$ in the components of the investigated heat pump

evaporator are almost the same (for daily heat production of $290 \mathrm{~kW} \cdot \mathrm{hr}$ in Fig. 2a) and cases in which this ratio is $10 \%$ in the compressor and $30 \%$ in the evaporator (for daily heat production of $50 \mathrm{~kW} \cdot \mathrm{hr}$ in Fig. 2a). A similar picture can be seen in Fig. $2 b$ for the sum of avoidable endogenous and avoidable exogenous exergy destruction $\dot{E}_{D, k}^{A V \Sigma}$. It should be noted that the shares 


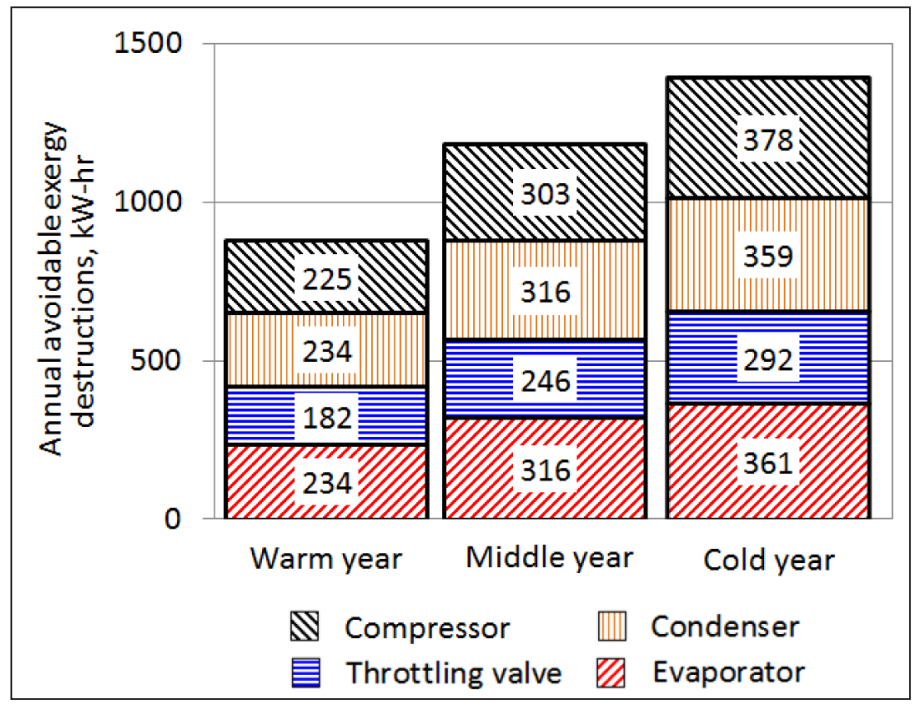

Fig. 5. Values of avoidable parts of seasonal exergy destructions $E_{D, k}^{A V \text { year }}$ in the components of the investigated heat pump for warm, middle and cold years

of the destruction of exergy in components of the heat pump depend on the heat source temperatures and supply-return temperature profile which is a function of the heat demand. So, it can be concluded that for correct exergetic assessment of the heat pump providing space heating it is not sufficient to analyse only a single operational mode (for example, design mode). Within a heating season both absolute values and the shares of exergy destruction can be different for different operational modes (see Figs. 1, 2) and it is proposed to calculate annual (for the whole heating season) values of exergy destruction $\left(E_{D, k}^{\text {year }}, E_{D, k}^{A V, \text { year }}, E_{D, k}^{A V, E N, \text { year }}, E_{D, k}^{A V, E N, \text { year }} E_{D, k}^{A V, \text {,year }}\right.$ and so on).

Using results obtained from the conventional (without splitting the exergy destruction) exergetic analysis (see the left bar in Fig. 3), the following conclusions can be formulated. The most important component from thermodynamic viewpoint is the condenser $\left(E_{D, C D}^{\text {year }}=783 \mathrm{~kW} \cdot \mathrm{hr}\right)$. The throttling valve has the second position $\left(E_{D, T V}^{\text {vear }}=682 \mathrm{~kW} \cdot \mathrm{hr}\right)$. The third position is associated with the evaporator $\left(E_{D, E V}^{\text {year }}=566 \mathrm{~kW} \cdot \mathrm{hr}\right)$. The compressor is the last important component from thermodynamic viewpoint $\left(E_{D, C M}^{\text {year }}=\right.$ $405 \mathrm{~kW} \cdot \mathrm{hr}$ ). If to compare these dissimilar components using the modified exergy destruction ratio $[2,3]$ that relates the exergy destruction within the kth component to the exergy destruction for the overall system, the components should be im- proved in the following order: condenser (32\% of exergy destruction ratio), throttling valve (28\%), evaporator (22\%), and compressor (17\%).

These results are misleading to some extent. For example, it can be concluded that in order to reduce the exergy destruction within the throttling valve we should try to improve this component. But a throttling process is completely irreversible and there are no ways of improving this process with the help of decreasing irreversibilities in it. Thermodynamic inefficiency in the throttling valve increases when the pressure ratio in it is also increased, which can take place due to bigger temperature differences in the condenser and evaporator. So, exergy destruction within the throttling valve can be eliminated with the help of improving condenser and evaporator but not the throttling valve itself. Also from the conventional analysis we obtain misleading information with respect to relative importance of the condenser and the evaporator. The matter is that the condenser has a higher exergy destruction without splitting but at the same time compared to the evaporator it can be characterized with a higher exergy destruction which cannot be avoided. As a result, thermodynamic inefficiency which can be really eliminated in this component can be lower than in the evaporator.

Taking into account the above-mentioned information we need more precise, detailed and additional information about irreversibilities 
within the system. This can be provided by advanced exergy analysis [1-4].

As can be seen from Fig. 3, only about $1181 \mathrm{~kW} \cdot \mathrm{hr}$ or $50 \%$ of the total annual exergy destruction in components of the heat pump can be avoided. The condenser and the evaporator have the same values of this part of exergy destruction $\left(E_{D, C D}^{A V \text { year }}=E_{D, E V}^{A V \text { year }}=316 \mathrm{~kW} \cdot \mathrm{hr}\right)$. Contrary to the conventional exergetic analysis, the advanced one provides us the information according to which the compressor has the value of avoidable exergy destruction very close to those of the condenser and the evaporator $\left(E_{D, C M}^{A V \text { year }}=303 \mathrm{~kW} \cdot \mathrm{hr}\right)$.

The results obtained from the advanced exergetic analysis indicate that the endogenous avoidable exergy destruction in the throttling valve is zero. This means that the exergy destruction within this component can be reduced through changes in the remaining components or in the structure of the overall system. Only $88 \mathrm{~kW} \cdot \mathrm{hr}$ of exergy destruction in the compressor can be avoided by improving this component. The endogenous avoidable exergy destruction in the evaporator is a little higher than this part of exergy destruction in the condenser $(336 \mathrm{~kW} \cdot \mathrm{hr}$ and $304 \mathrm{~kW} \cdot \mathrm{hr}$, respectively).

The biggest part of exergy destruction that can be avoided in the compressor is exogenous, i.e. can be eliminated through changes in the remaining components or in the structure of the overall system, and is equal to $E_{D, C M}^{A Y, E X \text {,year }}=215 \mathrm{~kW} \cdot \mathrm{hr}$. All thermodynamic inefficiency which can be avoided in the throttling valve is due to the remaining components or in the structure of the analysed heat pump. Very small values of avoided exogenous exergy destruction belong to the condenser and the evaporator. As can be seen from Fig. 3 about $40 \%$ of avoidable thermodynamic inefficiency is exogenous.

The data presented in Fig. 3 is provided in a more detailed manner in Fig. 4.

The seasonal exergy destruction which can be avoided with the help of improving the evaporator is equal to $564 \mathrm{~kW} \cdot \mathrm{hr}$ or $50 \%$ of the avoided exergy destruction in the heat pump. Improvement in the evaporator will affect not only the endogenous avoidable exergy destruction of this component $(336 \mathrm{~kW} \cdot \mathrm{hr}$ or almost all avoidable annual exergy destruction in this component), but also the exogenous avoidable exergy destruction within the throttling valve $(109 \mathrm{~kW} \cdot \mathrm{hr}$ or $44 \%$ of the annual avoidable exergy destruction in this component) and within the compressor $(118 \mathrm{~kW} \cdot \mathrm{hr}$ or $39 \%$ of the annual avoidable exergy destruction in this component). Similar results were obtained for the condenser, but the seasonal exergy destruction which can be avoided with the help of improving this component accounts for $43 \%$ of the avoided exergy destruction in the heat pump.

Due to variation of operational modes from year to year the values of exergy destruction in the same components of the investigated heat pump can be different. For example, in the analysed case avoidable parts of seasonal exergy destructions $E_{D, k}^{A \text { AYvear }}$ in the components of the heat pump for warm and cold years can be $14 . . .26 \%$ lower and bigger, respectively, as compared with a middle year.

Interesting information is provided by avoidable exogenous exergy destruction within the evaporator. It is negative $E_{D, E V}^{A V E X \text { year }}=-20 \mathrm{~kW} \cdot \mathrm{hr}$. This means that the exergy destruction within this component can be decreased by increasing irreversibilities within other components of the analysed heat pump. The similar information is obtained in [2] for the vapour-compression refrigeration machine with $\mathrm{R} 407 \mathrm{C}$ and in [3] for the absorption refrigeration machine.

Figure 6 illustrates the change of exergy destruction rates in the components of the investigated heat pump in the design mode after increasing the minimal temperature difference in the condenser $\delta T_{C D}^{\min }$ from $5 \mathrm{~K}$ to $9 \mathrm{~K}$. The product of the system remains the same for these two cases. From the presented results it is observed that after increasing the minimal temperature difference the exergy destruction rate in the evaporator was decreased from $0.211 \mathrm{~kW}$ to $0.206 \mathrm{~kW}$. Although in other components exergy destruction rates became higher which increased the total exergy destruction rate of the heat pump.

The graphical representation of thermodynamic cycles of the investigated heat pump in the design mode for the minimal temperature differences in the condenser $\delta T_{C D}^{\min } 5 \mathrm{~K}$ and $9 \mathrm{~K}$ on Ts-diagram is shown in Fig. 7. It can be observed that due to increase in minimal temperature differences in the condenser the initial 


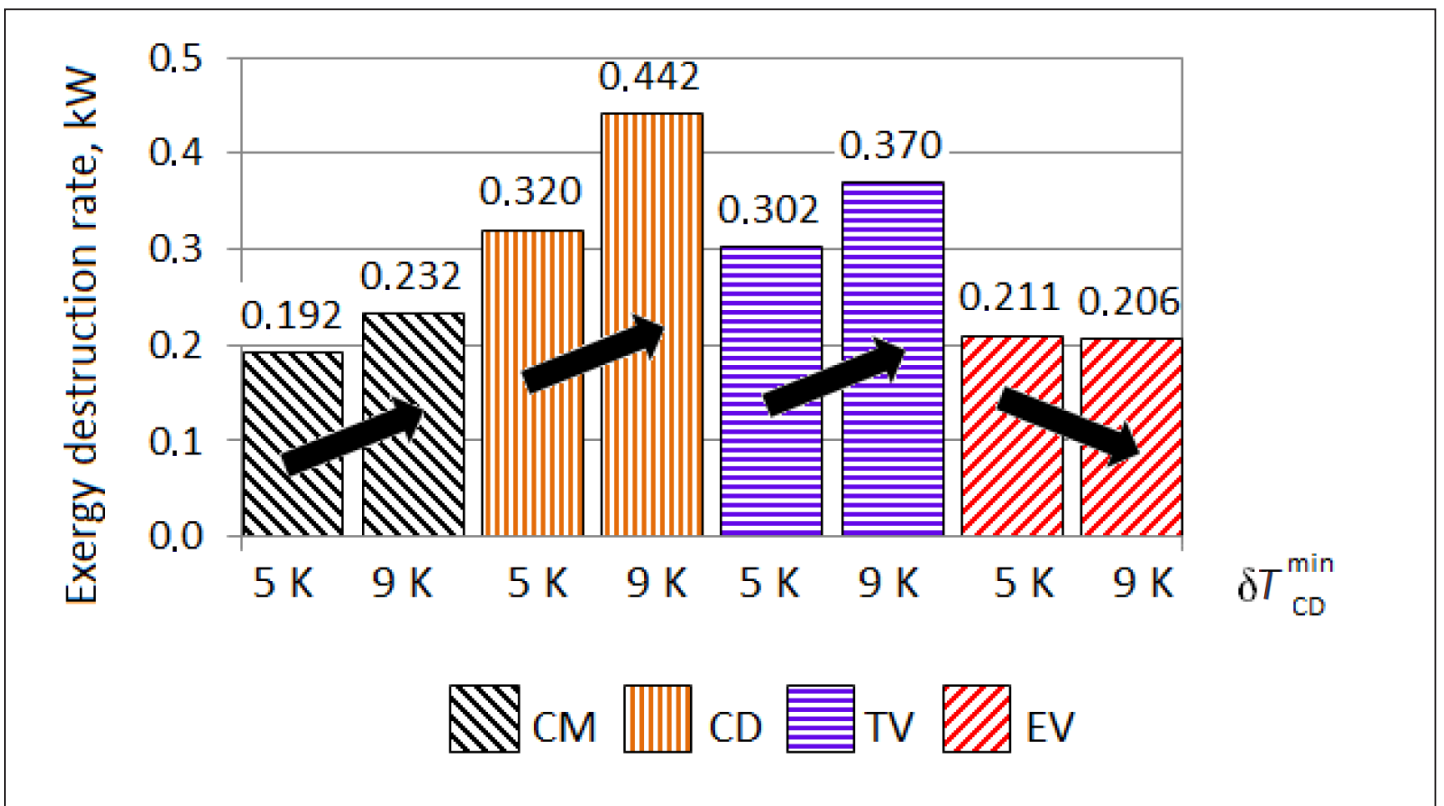

Fig. 6. Change of exergy destruction rates in the components of the investigated heat pump in design mode after increasing the minimal temperature difference in the condenser $\delta T_{C D}^{\min }$ from $5 \mathrm{~K}$ to $9 \mathrm{~K}$

thermodynamic cycle was changed. Point 1 (compressor inlet) remains the same $-1 \equiv 1$ '. Points 2 and 3 (condenser inlet and outlet) were moved higher and to the right - to 2' and 3' respectively. Point 4 (evaporator inlet) changed its location to the right - to 4. Changes of parameters of low temperature working fluid are also shown in Fig. 7. After increasing temperature differences in the condenser from $5 \mathrm{~K}$ to $9 \mathrm{~K}$ points 5 (low temperature working fluid at evaporator inlet) and 6 (low temperature working fluid at evaporator outlet) moved to the right. For convenience, the specific entropy of the low temperature working fluid was referred to $1 \mathrm{~kg}$ of R134A.

It is known that the exergy destruction rate depends on the mass flow rate $\dot{m}_{k}$ through

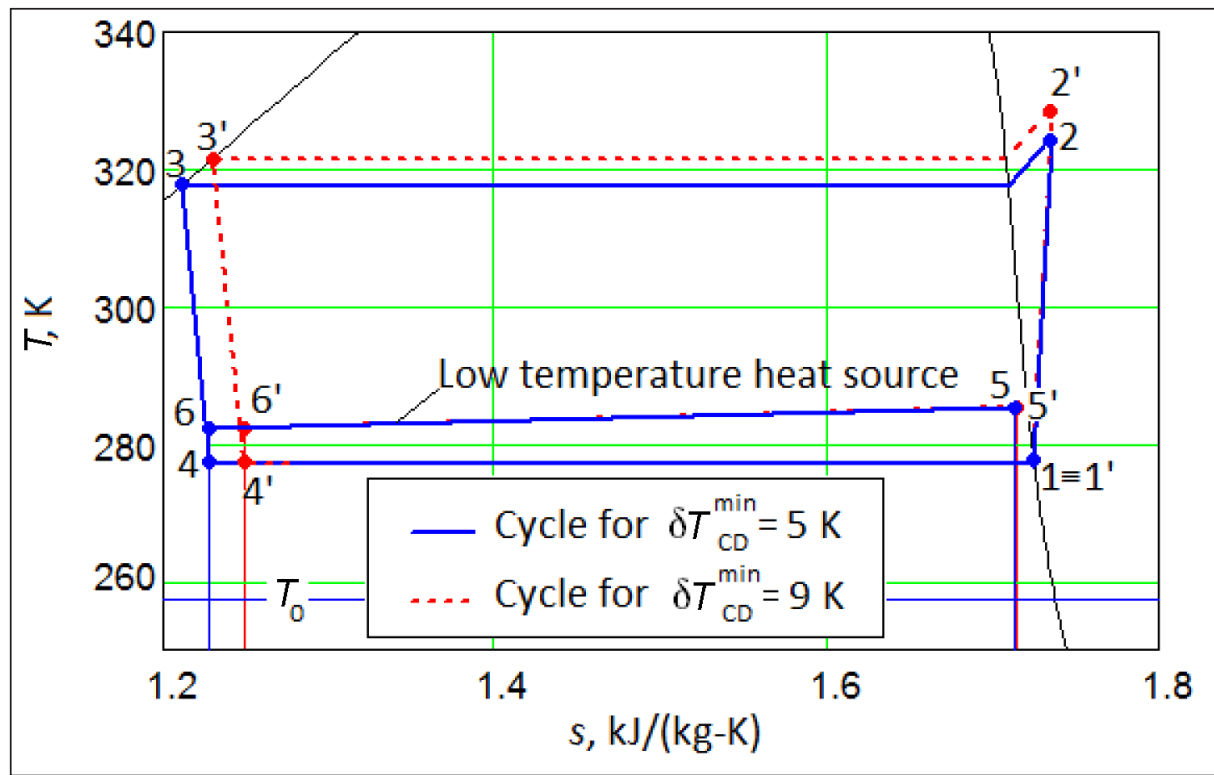

Fig. 7. Thermodynamic cycles of the investigated heat pump in design mode for the minimal temperature difference in the condenser $\delta T_{C D}^{\min } 5 \mathrm{~K}$ and $9 \mathrm{~K}$ 


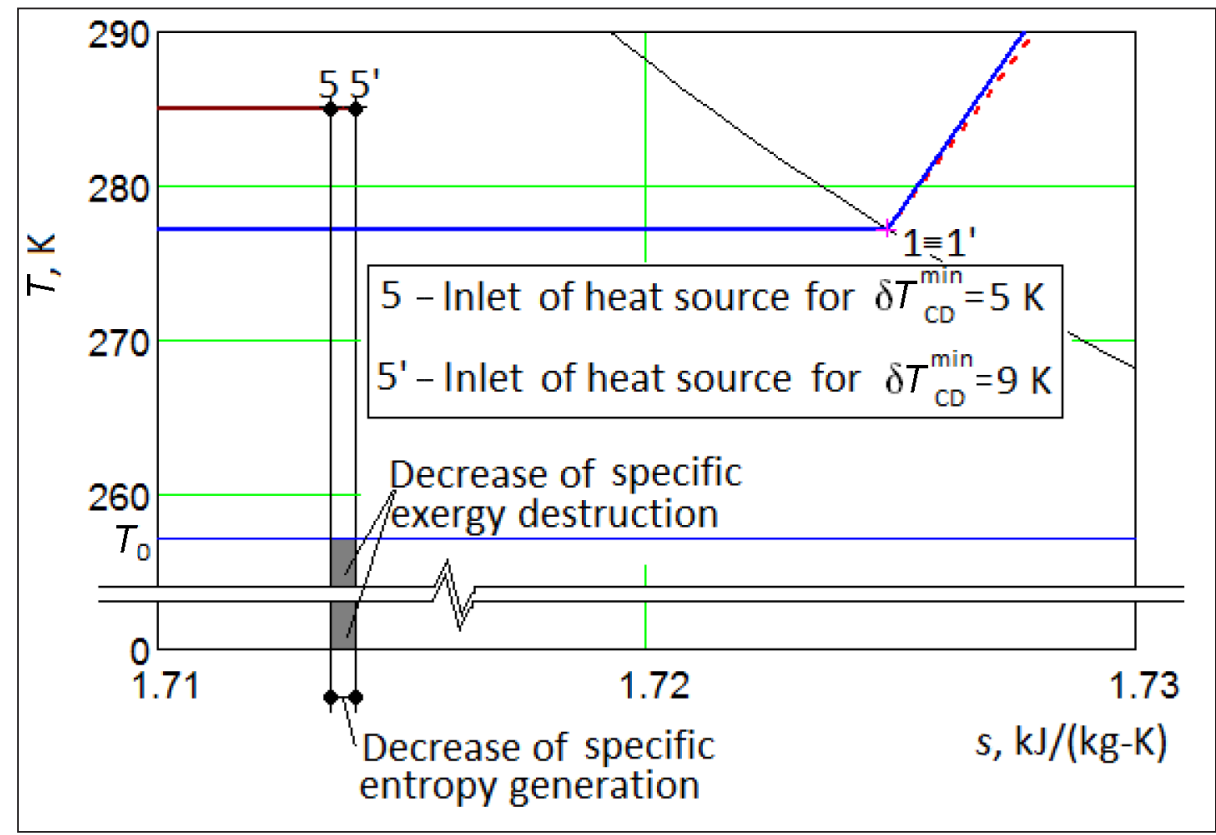

Fig. 8. Graphical illustration of exergy destruction decrease in the evaporator per unit of mass rate of R134A after increasing the minimal temperature difference in the condenser $\delta T_{C D}^{\min }$ from $5 \mathrm{~K}$ to $9 \mathrm{~K}$

the component and the specific entropy generation $s_{g e n, k}$ within it:

$$
\dot{\mathrm{E}}_{D, k}=T_{0} \dot{m}_{k} s_{g e n, k}
$$

where $T_{0}$ is reference temperature.

Using formula (3) it is possible to illustrate specific exergy destruction or its change on Ts-diagram. Figure 8 shows that after increasing the minimal temperature difference in the condenser from $5 \mathrm{~K}$ to $9 \mathrm{~K}$ the specific exergy destruction in the evaporator was decreased (highlighted area) because specific entropy generation became lower. Although the mass flow rate $\dot{m}_{E V}$ of R134A increased from $0.0721 \mathrm{~kg} / \mathrm{sec}$ to $0.0735 \mathrm{~kg} / \mathrm{sec}$, the increase in specific entropy generation outweighed this effect. As a result, exergy destruction rate in the evaporator was decreased from $0.211 \mathrm{~kW}$ to $0.206 \mathrm{~kW}$ (see Fig. 6).

\section{CONCLUSIONS}

1. When applying exergy analysis to heat pump systems providing space, the heating variation of operational modes within both the heating season and also from year to year should be taken into account. It is proposed to use annual (for the whole heating season) values of exergy de- struction. Values of exergy destruction calculated for single operational modes can lead to wrong conclusions because both the absolute values and the shares of exergy destruction in components of the system can be different for different operational modes.

2. In addition to conventional exergy analysis the advanced one has provided more precise information concerning location (in all four components of the heat pump exergy destruction takes place), magnitude (only $1181 \mathrm{~kW} \cdot \mathrm{hr}$ or $50 \%$ of the total annual exergy destruction in the heat pump can be avoided and is distributed among the components in the following manner: $303 \mathrm{~kW} \cdot \mathrm{hr}$ in the compressor, $316 \mathrm{~kW} \cdot \mathrm{hr}$ in the condenser, $246 \mathrm{~kW} \cdot \mathrm{hr}$ in the throttling valve, and $316 \mathrm{~kW} \cdot \mathrm{hr}$ in the evaporator) and causes (mostly due to irreversible heat transfer in the condenser and evaporator) of thermodynamic inefficiencies in the investigated heat pump.

3. According to the results obtained for the analysed heat pump due to variation of operational modes from year to year about $14 . .25 \%$ of annual avoidable exergy destruction in the components can differ from its value in a middle year.

4. Advanced exergy methodology also demonstrated that some amount of exergy 
destruction within the evaporator can be decreased by increasing irreversibilities within other components. But it does not mean that after this increasing the total exergy destruction within the system can be decreased - it becomes higher.

\section{ACKNOWLEDGEMENTS}

This work was supported by Ministry of Education and Science of Ukraine, project number $0116 \mathrm{U} 007384$.

Received 1 March 2017 Accepted 15 May 2017

\section{References}

1. Tsatsaronis G. Strengths and limitations of exergy analysis. Proceedings of the NATO Advanced Study Institute on Thermodynamics and the OPtimization of Complex Energy Systems, Neptun, Romania, July 13-24, 1998. Kluwer Academic Publishers. P. 93-100.

2. Morosuk T., Tsatsaronis G. Advanced exergetic evaluation of refrigeration machines using different working fluids. Energy. 2009. Vol. 34. P. 2248-2258.

3. Morosuk T., Tsatsaronis G. New approach to the exergy analysis of absorption refrigeration machines. Energy. 2008. Vol. 33. P. 890-907.

4. Tsatsaronis G., Morosuk T. Advanced exergy-based methods used to understand and improve energy-conversion systems. CPOTE-2016. Proceedings of the 4th International Conference on Contemporary Problems of Thermal Engineering, Gliwice - Katowice: The Silesian University of Technology Institute of Thermal Technology, September 14-16, 2016.

5. Erbay Z., Hepbasli A. Application of conventional and advanced exergy analyses to evaluate the performance of a ground-source heat pump (GSHP) dryer used in food drying. Energy Conversion and Management. 2014. Vol. 78. P. 499-507.

6. Erbay Z., Hepbasli A. Advanced exergy analysis of a heat pump drying system used in food drying. Drying Technology. 2013. Vol. 31. No. 7. P. $802-810$.

7. Herbas T. B., Berlinck E. C., Uriu C. A. T., Marques R. P., Parise J. A. R. Steady-state simulation of vapor-compression heat pump. International Journal of Energy Research. 1993. Vol. 17. P. 801-816.

Volodymyr A. Voloshchuk

\section{PATALPĄ ŠILDANČIO ŠILUMOS SIURBLIO PAŽANGI EKSERGINĖ ANALIZE்}

\section{Santrauka}

Be ịprastų eksergijos analizės metodų, pažangi ekserginè analizè numato energijos konversijos sistemos komponentų sąveiką ir realų kiekvienos sistemos komponento gerinimo potencialą.

Straipsnyje parodyta, kaip panaudota išsami ir pažangi ekserginė analizė nuotekų šaltinio šilumos siurbliui, užtikrinančiam patalpų šildymą. Siekiant nustatyti termodinaminius šaltnešio garų ciklo parametrus skirtinguose darbo režimuose buvo naudojamas skaitmeninis modelis. Analizė apima sunaikinamos eksergijos padalijimą kiekviename šilumos siurblio komponente $\mathfrak{i}$ endogenines ir egzogenines dalis, taip pat išsamų išvengiamą egzogeninès eksergijos sunaikinimo atskyrimą.

Atsižvelgiama ị pastato šilumos poreikio savybes tiek pasirinktais šildymo sezonais, tiek ir kiekvienais metais. Pateikiamas atskirtu sunaikinamos eksergijos dalių pasiskirstymas patalpai šildyti skirtame šilumos siurblyje įvairiais laikotarpiais. Parodyta, kad tiriamoje sistemoje galima išvengti tik apie $50 \%$ bendros šilumos siurblio sunaikinamos eksergijos per metus. Apie 30-40 \% šio išvengiamo termodinaminio neefektyvumo sukelia sąveika tarp komponentų. Remiantis taikyta pažangia eksergine analize, galima gauti tikslesnę ir naudingesnę informaciją siekiant geriau suprasti ir tobulinti analizuojamos energijos konversijos sistemos projektą ir veikimą.

Raktažodžiai: pažangi ekserginè analizė, šilumos siurblys, patalpų šildymas, kintamumas 